\title{
THE LAND QUESTION: POLITICAL ECONOMY OF LAND BANKING IN GHANA
}

\author{
Collins Adu-Bempah Brobbey*
}

\begin{abstract}
"The Land question" is an interrogation of the politics of land administration and its associated conflictsissues in the process of appropriating land in sub-Saharan Africa in general and Ghana in particular. The central argument of this paper is that in pre-colonial times, land was not considered a commodity because it did not have an exchangeable value, in other words, it was neither owned by individuals nor meant for sale, instead, it was communally owned and the king or the chief remains the only custodian of the land. However, when colonial administration took control over Africa, two things happened. Communally owned land process became formalized and consequently gave impetus to administrative land (State lands) and traditional land (Stool lands, also known as Land Tenure System (LTS). And subsequently, land was commoditized or, for wants of a better word, land became a saleable commodity. Consequently, communally owned land otherwise refers to in this paper as Traditional Land Bank and Banking for the indigenous was, however, replaced by what this paper refers to as "State-cum-Traditionalcum- Individuals Share equity". And surprisingly, land appropriation matters and its accompanied escalating conflicts bizarre had come to occupy center stage of land administration and appropriations discourses during and in post-colonial eras. Using peer reviewed articles, newspapers together with purposive in-depth interviews with stakeholders, traditional chiefs, land administrators, and individual land owners, this paper investigate the effectiveness of land administration and appropriation policy in Ghana. Findings revealed inconsistencies as a serious weakness of the existing land policy in Ghana and concludes that the emergence of commodification of land and its accompanied land appropriations turns to pose ominous challenge in the political economy of land acquisition and entitlement in the entire sub-Saharan Region of which Ghana is no exception. It recommends establishment of Land Banking system and to create land banks for easy and peaceful access to land ownership and usage. Also to serve as a recipe for land administrative and appropriating conflicts.
\end{abstract}

\footnotetext{
${ }^{*}$ Dr. Collins Brobbey Adu-Bempah holds a Doctor of Philosophy Degree in African Studies. He is a Senior Lecturer at the Ghana Institute of Journalism (GIJ), and a visiting Senior lecturer at the Institute of African Studies (IAS), University of Ghana, Legon. He is also a Visiting Assistant Professor, University for Peace (UPEACE) Addis Ababa Ethiopia, a Post-Doctoral Fellow (UPEACE-IDRC) 2014 and a laureate of UPEACE-IDRC Doctoral 2013 and Kennel Jackson Junior scholarship. He affiliates with Eurasian Multidisciplinary Institute, Africa \& Ghana Studies Associations (A/GSAs) and New Generation of Social Science Research Fellowship NGSSRF), among others. Research fields: African Politics, Public Policy Analysis Governance, Conflicts and Security Studies and Development. Email:cahbrobbey@gmail.com.
} 


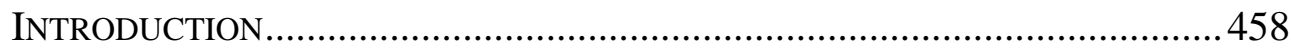

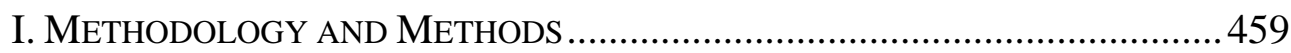

A. Methods and Information Gathering Techniques.......................4 460

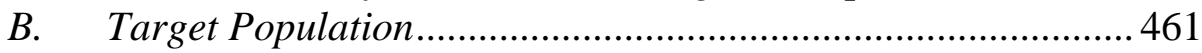

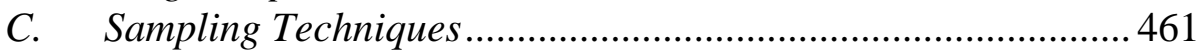

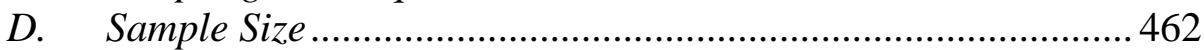

II. THEORETICAL AND CONCEPTUAL REFLECTIONS.......................................462

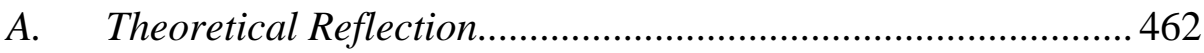

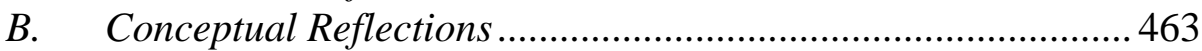

III. ANALYSIS OF CONCEPTUAL MODEL OF LAND BANK AND LAND BANKING

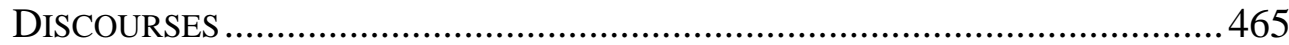

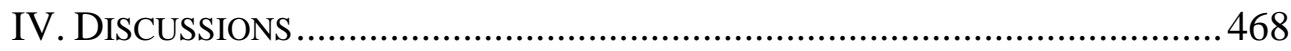

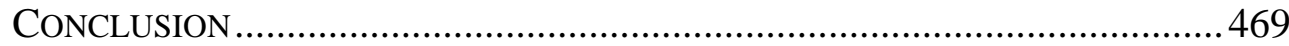

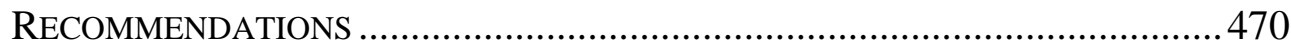

\section{INTRODUCTION}

"The Land question" is an interrogation of the politics of land administration and its associated conflicts in the process of administering and appropriating land in sub-Saharan Africa in general and Ghana in particular. The central argument of this paper is that in pre-colonial times, land was not considered a commodity because although it was useful in value but it did not have an exchangeable value, in other words, it was neither owned by individuals nor meant for sale, instead, it was communally owned and the king or the chief remains the only custodian of the land.

However, when colonial administration took control over Africa, two things happened. Communally owned land process became formalized and consequently gave impetus to administrative land (State lands) and traditional land (Stool lands), also known as Land Tenure System (LTS). And subsequently, land was commoditized or, for wants of a better word, land became a saleable commodity.

Consequently, communally owned land otherwise refers to in this paper as "Traditional Land Bank and Banking for the indigenous" was, however, replaced by what this paper refers to as "State-cum- Traditionalcum- Individual owner's equity". And surprisingly, land appropriation matters and its accompanied escalating conflicts bizarre have come to occupy center stage of land administration and appropriations discourses during and in post-colonial eras. What accounts for the ominous conflicts in land administration and appropriation in Sub-Saharan Africa in general and Ghana in particular and why? How could land problems be mitigated to 
ensure conflict-free access and usage of land in sub-Saharan Africa in general and Ghana in particular?

\section{Methodology AND Methods}

Scholarly works on administration and appropriation of land in subSaharan Africa in general and Ghana in particular is predominantly anthropological qualitative studies. Mostly, these studies have been focusing on disputes over land ownership which is often ethnocentric; hence those scholars have extensively used phenomenological theory including but not limited to the theory of clash of interests (converting residential land use to industrial land use) among others forms of disputes. In another paper the author argued that Greed theory (re-sale of land due to land value appreciation over time) Multiple Sales theory (selling one land to more than one person due to lack of appropriate documentation), Litigation theory (stool land wrongfully acquired either by individuals or by the state or using land for a purpose otherwise stated-land use impropriety) and Alternative Dispute Resolution (ADR) theory (favouritism in courts adjudicating land disputes) in attempt at explaining land disputes in sub-Saharan Africa including southern Ghana are very critical in elucidating the comprehensibility of land conflicts in sub-Saharan Africa.

Meanwhile, the author has argued that little attention has been paid to the administration and appropriation of land and its associated disputes over land ownership and shares similar view with Amanor (1999) ${ }^{1}$. Especially, there is scanty literature on the correlation between administration and appropriation of land and protracted conflicts which has bedevilled subSaharan Africa land administration. Thus the demographic characteristics involved in such conflicts, frequency of the case of land appropriation has not adequately been addressed empirically. There is inadequate analysis of land administration and appropriation policy in sub-Saharan Africa in general and Ghana in particular and so this paper seeks to plug this lacuna.

Meanwhile, epistemologically, this study deployed evolutionary theory with qualitative method to explain the dynamics, travails and the trajectories of administration and appropriation of land and its associated conflicts in sub-Saharan Africa in general and Ghana in particular.

\footnotetext{
${ }^{1}$ Kojo Sebastien Amanor, Global Restructuring and Land Rights in GHana: Forest Food Chains, TimBer AND RuRAL Livelihoods (Uppsala: Nordiska Afrikainstitutet 1999).
} 


\section{A. Methods and Information Gathering Techniques}

The choice of methods for any study is contingent upon the nature of the research. This paper reflects explanatory-exploratory nexus paradigm. The advantage of using this approach is, that they are not only suitable but also convenient especially, considering the fact that this paper focuses on activity and human-centered based ${ }^{2}$. Using peer reviewed articles, newspapers together with purposive in-depth interviews with stakeholders, traditional chiefs, land administrators, and individual land owners, this paper investigates the effectiveness of land administration and appropriation policy in sub-Saharan Africa in general and Ghana in particular.

For the secondary source, this study deployed scholarly articles obtained from JSTOR and African Studies Library including newspapers and some selected magazines. The primary source however, is the use of indepth face-to-face interviews, a qualitative research design for information gathering. The peculiarity of qualitative approach is that different opinions are simultaneously illustrated and gathered, also, words often depicts the qualitative data. This paper indeed, focuses on investigating administration and appropriation of land policy and its associated conflicts policy and generalizes the outcome.

In fact, qualitative research according to Kumar $(2013)^{3}$, is concerned with collecting and analyzing information in as many forms, generally nonnumeric. This type of research focuses on investigating in detail a situation with the aim of gaining "depth" instead of "breath" of a study. It therefore offers detailed information about the subject, with data which is "factual".

The qualitative method deployed in this study is motivated by Creswell (2012), Kumar (2013), assertion that the use of qualitative approach was not only a reflection of in-depth data, similarly, Creswell (2012) emphasizes that qualitative research exposes the social nature or the reality through the establishment of the relationship between the researcher and what is researched. In the same vein, it does not only address the situational constriction that gives the inquest its contour but also, qualitative research investigates people's environment and their actions in descriptive methods which most fairly represents the condition or situation as felt by the researcher. And hence Kumar $(2013)^{4}$ claims that using qualitative research approach guarantees reliability and also helps to validating sources thereby

\footnotetext{
${ }^{2}$ John W. Creswell, Research Design: Qualitative, Quantitative, And Mixed Methods APPROACHES. 3RD EDITION (Los Angeles: Sage Publications, Inc 2012).

${ }^{3}$ Kumar R., Research Methodology. A SteP by SteP Guide for BeginNers (3ND EDN) (Thousand Oaks, CA, Sage 2013).

${ }^{4}$ Ibid.
} 
effectively minimizing uncertainty. The research instruments of this paper were designed based on the foregoing, and hence the use of interview schedule or guide.

\section{B. $\quad$ Target Population}

The definition of research population reflects Creswell (2012) definition which sees the population as the study's object and is made up of individuals, groups, institutions, human dealings, or the circumstances to which they are exposed. In the context of this study, a population is a collection of possible participants to whom this study seeks to generalize the outcome of a study.

The target population is the population from which this study solicits views and also upon which the analysis is based. Besides, the research problem of his study also relates to a specific population, hence chiefs or kings, land administrators, policy experts in land administration and the primary stakeholders in the context of this study are considered as the macrocosm of elite group and the mass group consisting of primary, secondary and tertiary land dealers respectively.

This paper intends to establish the effectiveness of land bank and land banking as a recipe for administration and appropriation of land and its accompanied persistent disputes. Primary land dealers refer to the indigenes who traditionally are the landlords/owners of the land. The secondary land dealers also represent those who liaise between the landlords (owners) and the final land users. Whereas, the tertiary land dealers comprise of land administrators, and land users in land disputes.

\section{C. $\quad$ Sampling Techniques}

In settling on the sample techniques, this study was guided by Norman and Lincoln $(2013)^{5}$ assertion which states that a sampling technique is the procedure adopted when choosing the sample from a population to collect data relating to an incident or a phenomenon and whose views embody the population's interest. This paper therefore establishes the effectiveness of land bank and land banking as a recipe for administration and appropriation of land and its accompanied persistent disputesin Sub-Saharan Africa in general and Ghana in particular using a purposive sampling technique for selecting the respondents. The purposive sampling technique was used as

\footnotetext{
${ }^{5}$ Denzin Norman K. \& Yvonna S. Lincoln, Handbook of Qualitative Research (Thousand Oaks: Sage Publications, Inc. 2013).
} 
more or less the most suitable technique to choose the participants who understand the social dimensions of the problem understudy as well as providing the most vital responses to the research questions (Kumar, 2013; Norman \& Lincoln, 2013). The idea however is to, as Creswell (2012) puts it, "obtain an insider's exclusive perspective".

As it would be discussed in the analysis section, indeed, the selected respondents were not only fairly represented but also provided unique viewpoints on the issue of the effectiveness of land bank and land banking as a recipe for administration and appropriation of land and its accompanied persistent disputes in Sub-Saharan Africa in general and Ghana in particular. Since this paper intends to examine the efficacy of establishing land bank in Ghana, the land administration became inevitable and hence it was considered the best place to conduct the field study.

\section{Sample Size}

The in-depth interviews were conducted with 15 respondents purposively selected from among landlords, chiefs, Land economists, and land administrators, policy experts in land administration and primary stakeholders. In what follows, this paper examines the theoretical reflections of the effectiveness of land bank and land banking as a recipe for administration and appropriation of land and its accompanied persistent disputes in Sub-Saharan Africa in general and Ghana in particular by placing the administration and appropriation of land in context and in concert with evolutionary theory as a predictor of ominous challenges it poses on access and acquisition of dispute-free land.

\section{THEORETICAL AND CONCEPTUAL REFLECTIONS}

\section{A. Theoretical Reflection}

This paper adopts the evolutionary theory of land administration and appropriating rights to examine the laudability of establishing land banks for land banking project in sub-Saharan Africa and Ghana in particular because it is considered the dominant framework of analysis used by mainstream economists to assess the land tenure situation in developing countries. Also, to make prediction about its evolution. A central tenet of this theory is that under the joint impact of increasing commodification of land coupled with population pressure and market integration, land administration and appropriating rights spontaneously evolve towards rising individualization and that this evolution eventually leads rights holders to press for the 
creation of duly formalized private property rights - a demand to which the state often has an incentive to respond ${ }^{6}$.

This paper examines critically the efficacy of the value of the evolutionary theory of land rights as presently applied to Sub-Saharan Africa. In particular, the question of whether or not the establishment of private property rights is an advisable structural reform in the present circumstances is analyzed, in the light of evidence accumulated so far. It is argued that most of the beneficial effects usually ascribed to such a reform are grossly over-estimated and that, given its high cost, it is generally advisable to consider more appropriate solutions that rely on existing indigenous informal or traditional mechanisms at appropriating land at the community level.

\section{B. Conceptual Reflections}

Volumes of literature on administration and appropriation of land in sub-Saharan Africa point to the fact that state intervention in land matters have simultaneously resulted in inappropriateness and devastation of land use and accessibility. For instance economic scholars argue that traditional land rights in sub-Saharan Africa often lead to inefficient resource allocation. And that the inefficiencies are thought to arise because traditional land rights are not only ambiguous, communal, and afford insufficient protection in legislatures-resulting in tenure insecurity but also lead to inferior investment incentives, undersupply of credit, and constraints on efficiencyenhancing market exchanges. ${ }^{7}$

This argument has been advanced as a justification for government's action in land administration matters, and especially conversion to freehold titles in the Western strain ${ }^{8}$. Unfortunately, recent studies have challenged this view on the grounds that: (a) Traditional or custodian land rights are often neither communal nor ambiguous; (b) Traditional land tenure system is often flexible enough to cope with increasing land scarcity and to permit a gradual, "autonomous" individualization of rights, and; (c) State

\footnotetext{
${ }^{6}$ Ann Whitehead \& Dzodzi Tsikata, Policy Discourses on Women's Land Rights in Sub-Saharan Africa: The Implications of the Re-turn to the Customary, JOURNAL OF AGRARIAN CHANGE, DOI: 0.1111/1471-0366.00051 (17 January 2003).

${ }^{7}$ P. Domer, Lund Reform and EConomic Development (Harmondsworth: Penguin 1972); O. E. G. Johnson, Economic Analysis, the Legal Framework and Land Tenure Systems, 15 Journal OF LAW AND ECONOMICS 259 - 276 (1972); World Bank, Land Reform, Mimeo (Washington, DC: World Bank Development Series 1974).

${ }^{8}$ L. Alden-Wily, Land Tenure Reform and the Balance of Power in Eastern and Southern Africa. ODI Natural Resources Perspectives, 58 (2000).
} 
intervention in land matters often is more harmful than beneficial ${ }^{9}$.

A recent empirical study by Besley adds to this literature in an important way. Besley writes that:

The results in this paper reinforce the need for careful empirical studies of land rights and investment in low- income environments. They also reinforce the importance of understanding the determinants of rights as well as their consequences. Given the importance of investment to long-term poverty alleviation, it is important to understand what, if anything, governments can do. Developing land rights is often offered as a feasible intervention, especially in Africa. It would be premature to say that this does not work. However, the analysis of this paper warns against viewing it as a panacea for problems of low growth and investment before the process determining the evolution of rights is properly understood. ${ }^{10}$

In this paper the question of weaknesses in land administration and appropriation policy for land security and its conflict-frees access regarding demands as land becomes scarce and prices (implicit or explicit) rise are addressed. The issues are discussed within the context of sub-Saharan Africa; specifically where land initially is abundant and administration and appropriation of land rights have been shifting in the direction that enhances land practices dominated in sub-Saharan Africa, although the main points of this paper have application beyond this relatively narrow scope.

In the next section this paper briefly presents how conceptual models of issues land administration and appropriation and show how it has been viewed in mainstream property rights theory, as well as offer some common misgivings. In the subsequent section, it describes how land rights and land use could be enhanced through the development of land bank and banking in a typical sub-Saharan African community such as Ghana where land seem to have become scarce. It also develops a conceptual model which

\footnotetext{
${ }^{9}$ D. E. Ault \& G. L. Rutman, The Development of Individ-Ual Rights to Property in Tribal Africa, 22 Journal of LAW AND ECONOMics 63-182 (1979); R. H. Bates, Some Conventional Orthodoxies in the Study of Agrarian Change, 26 World Politics 234-254 (1984); J. W. Bruce, Land Tenure Issues in Project Design and Strategies for Agricultural Development in Sub-Saharan Africa, LTC Paper No. 128 (Madison: University of Wisconsin-Madison 1986); LTC, Security of tenure in Africa, Mimeo (Madison: University of Wisconsin. Land Tenure Center 1990); S. Migot-Adholla, P. Hazell, B. Blarel \& F. Place, Indigenous Land Rights Systems in Sub-Saharan Africa: A Constraint on Productivity?, 5 World Bunk ECONOMIC REvIEW 155-175 (1991); T. J. Bassett, Introduction: The Land Question and Agricul- Tural Transformation in Sub-Saharan Africa, in T. J. BASSETT AND D. E. Crummey (EdS.), LAND IN AFRICAN Agrarian SYSTEMS 3-31 (Madison: University of Wisconsin Press 1993); J. P. Platteau, Land Reform and Structural Adjustment in Sub-Saharan AfricaControversies and Guidelines, FAO Economic and Social Development Paper No. 107 (Rome: FAO, 1992).

${ }^{10}$ T. Besley, Property Rights and Investment Incentives: Theory and Evidence from Ghana, 103(5) JOURNAL OF POLITICAL ECONOMY 903-937 (1995).
} 
indicates the nature of land conflicts in land investment in the traditional tenure and freehold. In the penultimate section, it presents a discussion of the central issues, and the offer some concluding remarks and recommendation.

\section{ANALYSIS OF CONCEPTUAL MODEL OF LAND BANK AND LAND BANKING DISCOURSES}

The following is the presentation of the outline of the elements of the conceptual model of land Bank and Banking developed into models.

(1) Informalism/Custodianism:

Here ownership of land is considered Customary/Traditional or mirror the Land Tenure system and that the main characters of land administration are the Chiefs or the Kings as it may be implied.

(2) Formalism/Legalism:

This shows a shift of land entitlement to the state and hence land is considered as a Public Good, often referred to as Public/State lands and this resulted from the fact that the state is an agent to provide Land Security and also to use the land for Economic Infrastructural and Industrial purposes etc. The main characters are the Government, Land Commission, Land Title Registry, Surveying and Administration Departments.

(3) Commodification/Commercialization/Privatization:

Commodification or commercialization of land also further causes a shift in land ownership to private hands and hence land is considered as a Private Good secured and owned through Private property rights, and could further transfer the ownership through appropriating rights, for the purpose of establishing a Company, a factory, a Residential Facility, Agricultural and/or Farming, the main characters are the Individual, Partners and/or Joint Ventures.

(4) Land Bank/Land Banking:

The land bank and banking is a project that ensures that land ownership is constructed through the interplay of Traditional-cum-Public-cum-Privatecum-Partnership where the main characters are the Land Bankers known as the Estate Developers who may consist of the amalgamation or merger of chiefs, kings, private men, government authorities (especially, district assemblies etc.). The land bank is to operate as a normal banking institution to provide easy access to land at one-stop-office space or environment.

Meanwhile, the analysis of the conceptual model of Land Bank and Land Banking provides two scenarios. First, it elucidates the comprehensibility of the evolutionary theory of land administration and 
appropriation rights and second, it prescribes processes of acquiring a dispute-free land in any sub-Saharan region with particular concern about the Ghanaian situation.

As already indicated, the evolutionary theory deployed in this paper facilitates the explanations of the conceptual model of land administration and appropriation which this paper argues, has gone through chequred processes from pre-colonial through colonial to post-colonial times. This paper argues further that during pre-colonial times, land was not regarded as a commodity and therefore was not meant for sale but was always held in trust and in the custody of the chief or king as the case may be. However, the introduction of monetize economy during the colonial period gave impetus to the commodification and commercialization of land.

Consequently, two major but critical issues emerged. First, the status of land as informalized, custodianism or trusteeship was changed to Public good or state property as a result of state's ability or capability to secure land under a decoy of providing security and protecting the interests of the Custodians or trustees. Second, the manner in which state acquired the traditional land leaved much to desire. State, noted of its powerful agents otherwise known in superior-subordinate power relations term as "the powers that be" grabbed or appropriated traditional or custodian land otherwise known as "Stool lands" and arrogated to itself by re-label the land "State lands" or for wants of a better expression, "Government property." Accordingly, and as it is to be expected, it resulted in land conflicts to mark the genesis or hallmark of protracted land conflicts otherwise came to be known as "The land Question."

Unfortunately, however, the infractions caused by state in land appropriation subsequently opened the floodgate of land commodification and commercialization given further impetus to escalating land conflicts whose end history has not yet been revealed. The conceptual model is thus, a true account of how custodian land has been misappropriated over the years.

Indeed, land conflicts have since time immemorial, seen no end simply, because the conflicts are both complex, complicated and multifaceted and which cannot be addressed without resorting to empirical approach. The layers of the land conflicts' question involves phases of land grabbing and appropriation. For instance, conflicts ensue between traditional informalized or custodian land tenure system- cum- formalized state or government (The so-called "powers that be") cum- individual-cum- private partners. Or, between traditional informalized or custodian land tenure system- cum- their own royals of the land-cum-formalized state or government (The so-called 
"powers that be")- cum- individual-cum- private partners and so on and so forth (See the onceptual Model of the nature of Land Conflicts in Ghana below Figure 1).

Customary/Traditional Land Tenure System (Chief King)

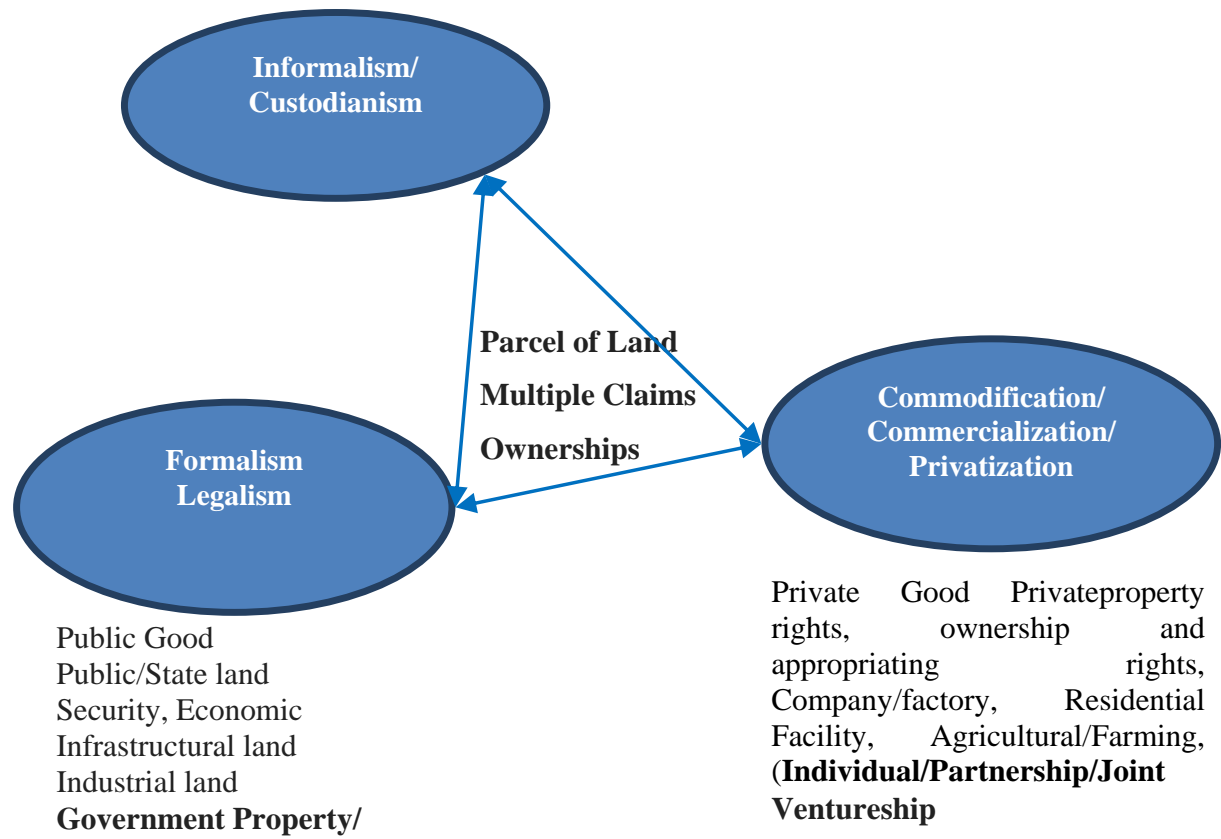

Land Commission, Land Title

Survey and Administration

Figure 1 Conceptual Model of the Nature of Land Conflicts in Ghana.

In attempt at finding lasting solution to the land impasse, this paper prescribes aconceptual Model of Land Bank and Banking as a recipe for the land administration and appropriation challenges (Figure 2). 


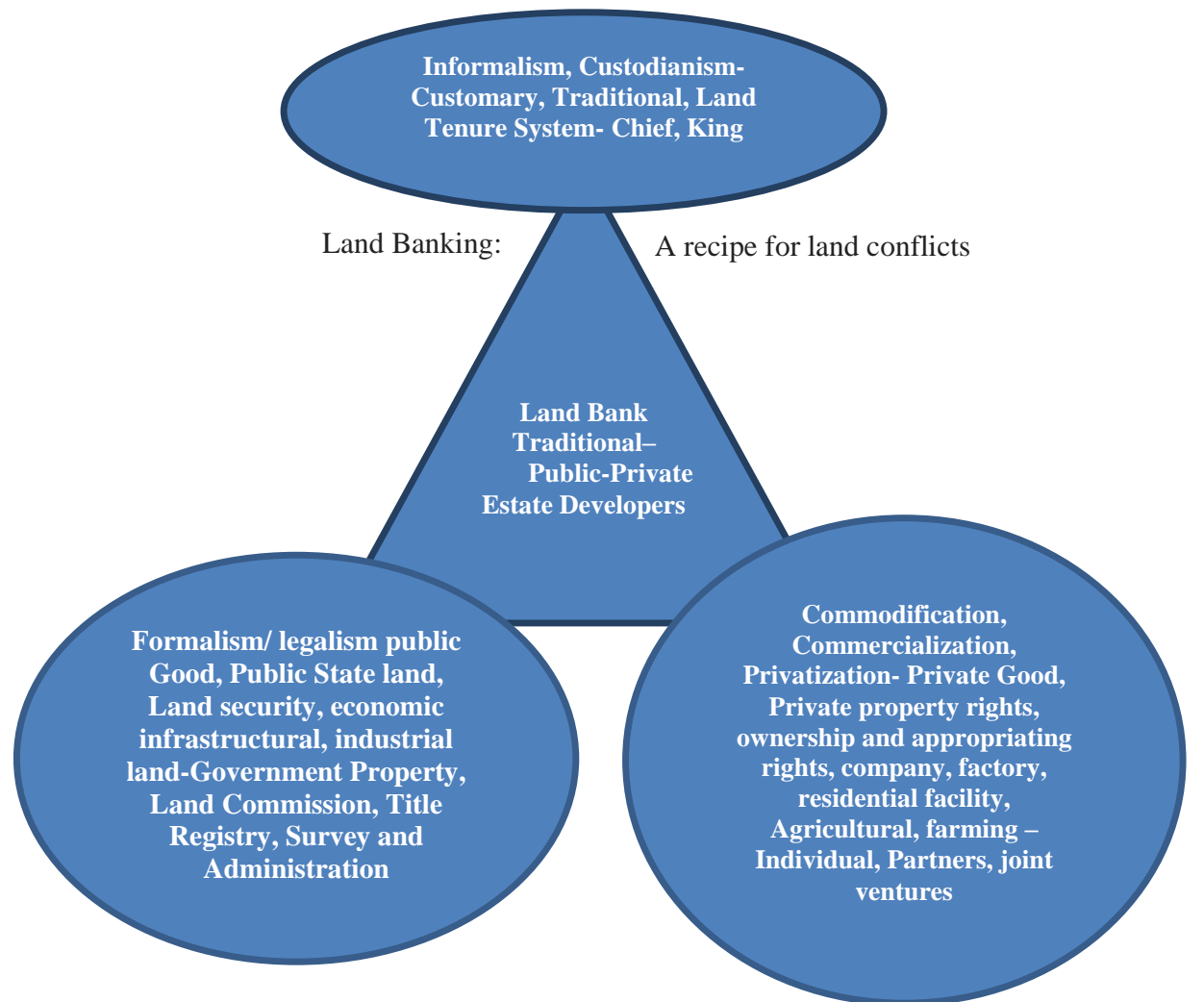

Figure 2 Conceptual Model of Land Bank and Banking: A Recipe for Land Administration and Appropriation Challenges.

From the analysis of conceptual model of land Bank and Land Banking above, this paper has succeeded in demonstrating how a particular "stool land" or custodian land could be accessed or owned without necessarily meeting the custodian of the land and also avoiding possible conflicts of interest associated with land acquisition, administration and appropriation in sub-Saharan Africa in general and Ghana in particular.

\section{DISCUSSIONS}

As already indicated, in this paper it conducted an examination of existing policy discourses on land reforms in sub-Saharan Africa in general and Ghana in particular and the ramifications of the administration and appropriating land. This paper presents a number of interesting and insightful revelations.

First of all, one of the revealing findings is the serious inconsistencies in the land policy direction regarding administration and appropriating land, 
which did not only corroborate the position of this paper but also is considered a critical weakness of the existing land policy in sub-Saharan Africa of which Ghana is no exception. In an interview conducted with primary and secondary land dealers, it was revealed that an emerging consensus among a range of influential policy institutions, lawyers and academics about the potential of land commodification enterprise to meet the needs of all land users and claimants has given impetus to ominous challenges of land acquisition and ownership or land property rights.

Consequently, consensus has arisen out of critiques of past attempts at land titling and registration, particularly in Ghana, Kenya and Ethiopia, which has hitherto been rooted in modernizing discourses on evolutionary theories of land administration and appropriating rights. It however, embraces particular contested understandings of indigenous traditional land bank and banking discourse as well as the law and legal pluralism, thereby turning to feed into a wide-ranging critique of the failures of the postcolonial state in Africa, given way to the expression of the current retreat of the state under structural adjustment programmes.

Interviews with some primary stakeholders including land administrators, lawyers and academics representing the macrocosm of land policy experts, revealed that chiefs who are the custodians of land rather constitutea minority dissenting voice though, however, they are much more equivocal about trusting the customary, preferring instead to look to the State for laws to protect individual's property rights to land or interests. While this paper recognizes the fact that there are considerable problems with customary systems of land tenure and administration for achieving dispute-free access to land and also ensure justice with respect to individual's land claims. This paper, however, posits that insufficient attention is being paid to power relations in the administration and appropriating land in the countryside and hence the negative implications of land commodification for land users who are not well positioned and represented in local level power structures.

That notwithstanding further finding confirmed that considerable changes to political and legal practices and cultures are needed before African states could establish land bank and land banking project which would serve to deliver dispute-free access and ensure justice with respect to land administration and appropriation.

\section{CONCLUSION}

This paper concludes that there is a connection between land rights 
appropriation, land tenure security, and high investment demand for land in sub-Saharan Africa. And this gave impetus to the common assertions regarding indigenous tenure assuming; (a) insecurity of tenure leading to suboptimal investment incentives; and (b) appropriation of land rights in the public domain promoting rent-dissipating or rent-seeking.

And that land use and investment decisions among Africans often have two motives: productivity and rights appropriation. The usual assertions thus seem contradictory. It therefore offers a conceptual model to show that land bank and banking may provide equal, easy or higher investment incentives than indigenous tenure, state and private rights, and may promote modes of rights appropriation that are productive rather than wasteful.

Finally, it concludes that the emergence of commodification of land and its accompanied land appropriations turns to pose ominous challenge in the political economy of land acquisition and entitlement in the entire subSaharan Region of which Ghana is no exception.

\section{RECOMMENDATIONS}

It recommends establishment of Land Banking system and to create land banks for easy and peaceful access to land ownership and usage. And also to serve as a recipe for land administrative and appropriating conflicts bedeviled sub-Saharan Africa in general and Ghana in particular. 